\title{
The benefits of smoking cessation on survival in cancer patients by integrative analysis of multi- omics data
}

Sheng Yang ( $1024227634 @ q q . c o m$ )

Southeast University https://orcid.org/0000-0002-0485-7728

Tong Liu

Southeast University

Geyu Liang

Southeast University

\section{Research}

Keywords: current smokers, reformed smokers, smoking signature, prognosis

Posted Date: June 17th, 2020

DOI: https://doi.org/10.21203/rs.3.rs-28649/v2

License: (c) (i) This work is licensed under a Creative Commons Attribution 4.0 International License.

Read Full License 
The authors have withdrawn this preprint from Research Square 